P edagogia : Jurnal Ilmu Pendidikan

\title{
EFEKTIVITAS PENGGUNAAN MULTIMEDIA INTERAKTIF DAN MOBILE LEARNING DALAM MENINGKATKAN HASIL BELAJAR PADA MATA PELAJARAN MATEMATIKA
}

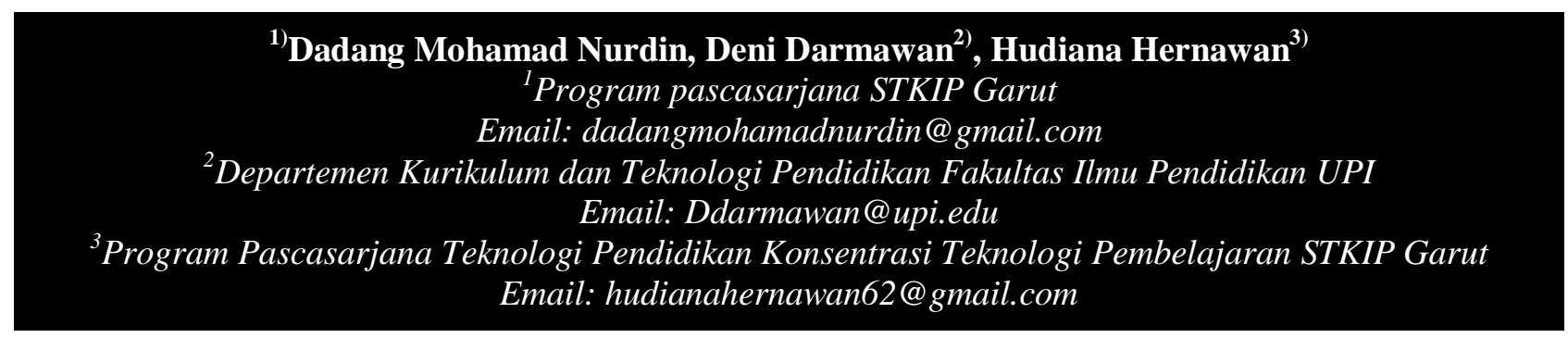

\section{Abstract}

The purpose of this study is (1) to determine the learning outcome of students using interactive multimedia; (2) the improvement of student learning outcomes using mobile learning; (3) to determine the differences between the learning outcome of students using interactive multimedia and mobile learning. The method used is the method of quasi-experimental research design used in this study The Static group pretest - posttest design. Results obtained indicate that (1) there is an increase in student learning outcomes which uses interactive multimedia; (2) there is an increase in student learning outcomes using mobile learning; (3) there are differences between the learning outcome of students using interactive multimedia and mobile learning.

Keywords : Interactive Multimedia, Mobile Learning, and Learning Outcomes 